\title{
APPLICATION OF SHORT DIAGNOSIS AS AN ERGONOMIC INTERVENTION TOOL IN A SAWMILL IN AMAZONIA
}

\section{APLICAC̄ÃO DO DIAGNÓSTICO CURTO COMO UMA FERRAMENTA DE INTERVENÇÃO ERGONÔMICA EM UMA SERRARIA NA AMAZÔNIA}

\author{
Agberto de Castro Marinho Júnior E-mail: agbertojunior@gmail.com \\ Moisés Andrade Coelho*E-mail: moises.acoelho@gmail.com \\ *Instituto de Ciências Exatas e Tecnologia (ICET), Universidade Federal do Amazonas (UFAM)
}

\begin{abstract}
This work aims to apply the Short Diagnosis in a sawmill in Amazonia. The originality of this work lies in the application of an ergonomic intervention method that allows the identification of initial ergonomic demands, as well as aspects related to the improvement of the production process, work systems and the organization as a whole. Regarding the approach to the problem, this study is characterized as qualitative and exploratory in terms of objectives. From the standpoint of technical procedures, action research was used in this study in the form of a case study. The sample used in the study was intentional non-probabilistic. The main results stand out, the application of the Short Diagnosis approach that allowed the enterprise's knowledge in a short period of time; providing insights for future projects due to the identification of points of improvement related to production and management factors; recognition of ergonomic aspects in the observed activities; improved the enterprise's internal communication, and recommendations for organizational and ergonomic projects. Considering the theoretical and practical implications, the work enriches the literature related to the application of ergonomic intervention methods, in addition to pointing out the relevance of the Short Diagnosis as a practical tool for organizations of different sizes.
\end{abstract}

Keywords: Ergonomics. Methods. Activity analysis.

Resumo: Este trabalho tem como objetivo aplicar o Diagnóstico Curto em uma serraria na Amazônia. A originalidade deste trabalho reside na aplicação de um método de intervenção ergonômica que permita identificar demandas ergonômicas iniciais, bem como aspectos relacionados à melhoria do processo produtivo, dos sistemas de trabalho e da organização como um todo. Com relação à abordagem do problema, este estudo caracteriza-se como qualitativo e exploratório quanto aos objetivos. Do ponto de vista dos procedimentos técnicos, a pesquisa-ação foi utilizada neste estudo na forma de um estudo de caso. A amostra utilizada no estudo foi não probabilística intencional. Destacam-se como principais resultados, a aplicação da abordagem de Diagnóstico Curto que possibilitou o conhecimento da empresa em um curto período de tempo; fornecendo insights para futuros projetos devido à identificação dos pontos de melhoria relacionados aos fatores produtivos e de gerenciamento; reconhecimento dos aspectos ergonômicos nas atividades observadas; melhorou a comunicação interna da empresa, e recomendações para projetos organizacionais e ergonômicos. Considerando as implicações teóricas e práticas, o trabalho enriquece a literatura relacionada à aplicação de métodos de intervenção ergonômica, além de apontar a relevância do Diagnóstico Curto como ferramenta prática para organizações de diversos portes.

Palavras-chave: Ergonomia. Métodos. Análise da atividade.

\section{INTRODUCTION}


The timber sector occupies a prominent position in the social and economic scenario at the global and Brazilian levels, as wood is one of the main raw materials in many segments of the economy, such as construction and furniture manufacturing (VIDOR et al., 2010). Standing out for being a sector of the Brazilian economy of great representativity, given the generation of income, taxes, foreign exchange, and jobs (NUNES; MELO; TEIXEIRA, 2012).

In this segment, sawmills have always been prominent in the number of companies as well as in wood consumption (ELEOTÉRIO; STORCK; LOPES, 2012), making Brazil appear in the international context as the 11th largest lumber producer in the world (Associação Brasileira dos Produtores de Florestas Plantadas - ABRAF, 2012). The sawmills came up with a tool capable of turning wood into raw material, and gradually had to increase machinery in their work process, but although it is of great importance, the sawmill activity is mostly performed under adverse conditions, in particular to the physical integrity of the human being, who remains exposed to unfavorable work environments: inappropriate weather conditions; high noise levels; poor lighting and inadequate postures (CULCHESK et al., 2015).

Occupational health and safety encompass the social, mental and physical well-being of workers through health and safety measures that require the collaboration and participation of both employers and workers in health and safety programs, forcing them to address issues related to occupational medicine, occupational hygiene, toxicology, safety engineering, ergonomics, among others (BUREAU INTERNACIONAL DO TRABALHO, 2009).

The Short Diagnosis is a generalist approach, conducted by individuals with different skills, its analysis is centered on work situations and its results constitute aid to future project definitions (DELTOR; GUÉRIN, 1994). The results of the Diagnosis have a pedagogical medium and observation is the occasion to contextualize general reasoning about the importance of considering real work for any intervention on the work system (SILVA, 2007).

Thus, this paper aims to apply the Short Diagnosis in a sawmill located in Amazonia as an ergonomic intervention tool. The work is divided into three parts: (1) literature review dealing with ergonomics and short diagnosis; (2) methodology; and (3) results, conclusion and references. 


\section{LITERATURE REVIEW}

\subsection{Ergonomics}

According to Dul \& Weerdmeester (2004), ergonomics also called human factors is a scientific discipline that studies the interactions of men with other elements of the system, making applications of theory, principles and design methods to favor human well-being overall system performance. Ergonomics emerged in England after World War II through the creation of the first ergonomic society, physiologists, architects, designers, and economists to create the first ergonomic society - Ergonomics Research Society (LAVILLE, 2007).

Ergonomics is a science that aims to solve problems of the relationship between man, machine, equipment, and tools, that is, it solves conflicts between man and the technology applied to his work (MORAES; MONT'ALVÃO, 2000). It also helps to reduce problems related to health, comfort, and efficiency during the development of activities, reducing the risks of occupational accidents (CAMFIELD et al., 2006).

lida (2005), in turn, points out that ergonomics is the study of the adaptation of work to man, and the work is not only that performed with machines and equipment, but the whole relationship situation between a man and a productive activity.

The Regulatory Standard (NR-17) regarding ergonomics aims to establish parameters that allow the adaptation of working conditions to the psychophysiological characteristics of workers, in order to provide maximum comfort, safety, and efficient performance. This should apply to companies whose working conditions include aspects related to the lifting, transport, and unloading of materials, furniture, equipment and environmental conditions of the workplace and the organization of the work itself (Brasil, 1978e).

In terms of ergonomic objectives, lida (2005) states that ergonomics seeks the safety, satisfaction, and well-being of workers in their relationship with production systems. Knowing that production systems evolve with the development of technology, as machines every day take on heavy work, increasing productivity and product quality, man is assigned mental and sensory effort. 
With this, it is important to recognize that companies invest in ergonomics. There are several reasons because, in addition to the return on investment project, it includes the ethical obligation to provide a safe, regulatory compliant work environment while remaining competitive in the market for the most talented employees and in accordance with collective bargaining (HUGHES; NELSON, 2009). In this sense, Miles \& Perrewe (2011) explain that through ergonomics such as: reducing medical costs, reducing absenteeism and improving worker satisfaction is a way to protect organizational assets making the company more competitive in the market.

\section{a) Ergonomic Action}

Ergonomic action takes into consideration criteria such as workers' health and also criteria related to the efficiency of productive action, which may lead to different theoretical and methodological orientations, seeking to clarify the productive performance and the consequences of the activity for the people involved, that is, Ergonomic action seeks both effects on people and effects on the company. The criteria of ergonomic action must be carefully analyzed for each intervention, as ergonomics has a specificity of problems with different concepts that must be respected (DANIELLOU; BÉGUIN, 2007).

Abrahão et al. (2009), explains that in ergonomic action there are own analysis methods and techniques to identify the problems caused to man by the inappropriate use of artifacts, work organization and environments, seeking solutions for the worker to have comfort, quality, efficiency. and effectiveness. The knowledge used or studied in ergonomic action is structured according to the demands of intervention, and situations alternate and present particularities that can be analyzed through previous work for the diagnosis of new situations.

The ergonomic action has the purpose of modifying work, this modification contributes to the perception of work that does not change workers' health, as well as to achieve economic goals pre-defined by the company (GUÉRIN et al., 2001).

The specificity of ergonomic action, which aims at action, is the dynamic relationship between the demand that the ergonomist has agreed to address; the means made available to them; choosing the work situations he will seek to analyze more accurately; the determinants and dimensions of the activity, the analysis of which he 
will narrow down; the possible outputs that he identifies in the situation, and especially the social forces capable of advancing the treatment of the problems raised (DANIELLOU; BÉGUIN, 2007).

\section{b) Short Diagnosis}

The short diagnosis is centered on the analysis of work situations and its results are an aid to future projects. It corresponds to a stage that aims to identify the issues related to the content, the conditions of the work, as well as its organization in the elaboration and conduct of change or investment projects (DELTOR; GUÉRIN, 1994).

Considering the studies by Deltor \& Guérin (1994) in which presents the direction of the short diagnosis starting from the demand and ending in the action, mentioning the three basic steps (demand analysis, diagnosis and put in motion), as shown in Figure 1.

Figure 1 - Short diagnosis direction.

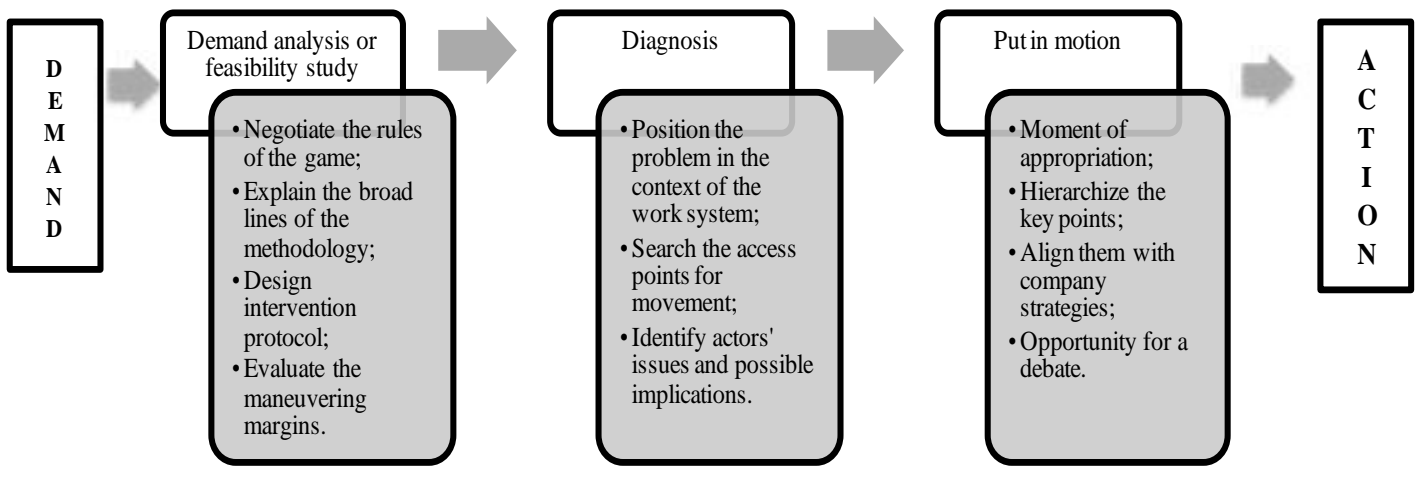

Source: Adapted from Deltor \& Guérin (1994).

According to Coelho, Albuquerque \& Vaz (2015), the short diagnosis has several benefits, namely: it allows an evaluation in a short period of time, it allows a knowledge of the company and its demands, it provides senior management with insights for application in future projects, improves internal communication, as well as promoting an organizational debate to enable possible changes. 
The results of the short diagnosis should enable workers and their representatives (unions, for example) to identify what the diagnosis reveals to them in the context of the changes envisaged. The diagnosis is then able to open a space for debate or even negotiation (SILVA, 2007).

The short diagnosis enables a dialogue between employees and senior management about the ergonomic conditions of the company for future improvements. The use of this approach by professionals in the area of ergonomic work analysis (ETA) has allowed relevant diagnoses and enriching transformation projects (SILVA, 2007).

As mentioned, the Short Diagnosis was developed in France in 1990 by ANACT (National Agency for the Improvement of Working Conditions) to serve French small and medium enterprises (DELTOR; GUÉRIN, 1994).

In Brazil, Silva (2007) applied Short Diagnosis to a medium-sized company in the remolded tire manufacturing industry in conjunction with the Ergonomic Checkpoints (FUNDACENTRO, 2001) and the postural analysis tool "OWAS". In an article, Assunção et al. (2010) described working conditions in micro and small businesses in the food and beverage sector and assessed workers' health and workability by analyzing social security data and periodic medical examination records. To observe the working conditions, the authors prepared fact sheets for the Short Diagnosis application in the 32 companies involved in the study.

Costa et al. (2015) presented a Rapid Diagnostic Methodology (MDR) in ergonomics to evaluate a set of platforms allowing to reveal general principles to systematize situations that should improve and understand broad processes. The main advantage of applying MDRs is the faster return of results to social actors, being an effective tool for the construction of strategic actions in ergonomics. Coelho, Albuquerque \& Vaz (2015), performed the application of Short Diagnosis in a small confection located in the city of Manaus. The authors point out the ease of application of the approach allowing the knowledge of the company in a short period of time, as well as providing insights for future projects.

Aract (2009) developed Elvie, a diagnostic and prevention tool for work situations related to psychosocial risks. Psychosocial risks result from the action and combination of professional determinants in conjunction with the constraints of work. These types of risks include stress, suffering, violence, and harassment in the work- 
place. Elvie is built in three parts: (1) problem expression, (2) problem determinant analysis, and (3) understanding of the problem actors' experience.

In conclusion, the International Labor Organization (ILO) and the International Ergonomics Association (IEA) developed the Action Checklist for Agriculture instrument. The checklist is an instrument developed specifically for agricultural production processes and presents practical solutions for improving agricultural work and rural life from an ergonomic point of view (ILO - International Labour Office; IEA - International Ergonomics Association, 2014).

Checkpoints summarize essential actions and can be used as a starting point for designing particular workplaces. The manual is used to assess existing working conditions and to implement improvements in different situations (ILO \& IEA, 2014).

\section{METHODOLOGY}

Regarding the approach to the problem, the study used qualitative research (SILVA; MENEZES, 2005; GUERRA, 2014). The main subject is the researcher, whose duty is to collect data directly from the environment that will be studied through interviews, a questionnaire among others.

Regarding the objectives, this work is classified as exploratory research, as it seeks to describe the characteristics of a given population or phenomenon or establishing relationships between variables in the case of the sawmill studied (SILVA; MENEZES, 2005).

From the point of view of technical procedures, action research was used for this study as a case study. In which action research is a research strategy that aims to produce knowledge and solve a practical problem (MELLO et al., 2012). The case study refers to the most in-depth survey of a particular case or human group in all its aspects (MARCONI; LAKATOS, 2008).

The research universe was delimited by the accessibility criterion in a lumber enterprise located in the state of Amazonas/Brazil. The enterprise studied has 18 employees, 16 males, and two females, with varying levels of education (elementary school to higher education), some of them admitted by outsourced contracts. Employees are based in the following sectors: Administrative, where management, hu- 
man and financial resources (purchasing and sales) are located, and the production sector, which includes maintenance, inventory, and sawdust.

Regarding data collection, a non-probabilistic intentional study was used because the sample selection did not occur randomly (Marconi \& Lakatos, 2008). Regarding research techniques, we used: (1) indirect documentation through documental and bibliographic research. We also used (2) intensive direct observation through observation and interview, and (3) extensive direct observation through the application of forms.

Initially, individual open structured interviews were conducted with the enterprise manager, based on a script that sought to identify the initial information of the enterprise and the department from the interviewee's point of view. The individual interviews lasted approximately 120 minutes.

Then a form was applied to the production supervisor and collaborators. This form was based on (GUÉRIN et al., 2001) in order to identify several aspects to characterize the initial demand.

In the application of the Short Diagnosis, five visits were made to the enterprise studied, in which two were made in the administrative area and three visits in the productive area. The visits took place during the morning. Regarding the observation of activities, the approach proposed by Guérin et al. (2001), in which, from the individual interviews (demand) the observer performed a brief analysis of the tasks.

The activities of the employees of workstation 1 (seraphite) and the employees of workstation 2 (multi-blade) were monitored in order to understand the activities of these sectors. It is considered observable, gestures, postures, actions, communications between employees of the above-mentioned sectors, as well as communications with other areas administration, maintenance and sales. It used a form to note the observables, containing: time (of each activity); place (where the activity took place); action (what was done); and communication (verbal, gestural and postures).

Regarding the data analysis, the answers obtained through the questionnaire were organized in table form represented in the summary table form, grouped according to the content and stratified according to the structure of the questionnaire. As explained by Marconi and Lakatos (2008) tables or frames are a method of presenting data in vertical columns or horizontal rows, which obeys the classification of research objects or materials. 
While the information extracted from observation and verbalization was associated and triangulated with the information collected in the interview in order to secure the rationalization and validation built.

With respect to data analysis, the period was three days for the completion of the Short Diagnosis report, and for the application of Short Diagnosis in the enterprise under study, counting the time of application, data analysis, preparation and presentation of the report, it took nine days, as shown in Figure 2.

Figure 2 - Distribution of execution of activities (days).

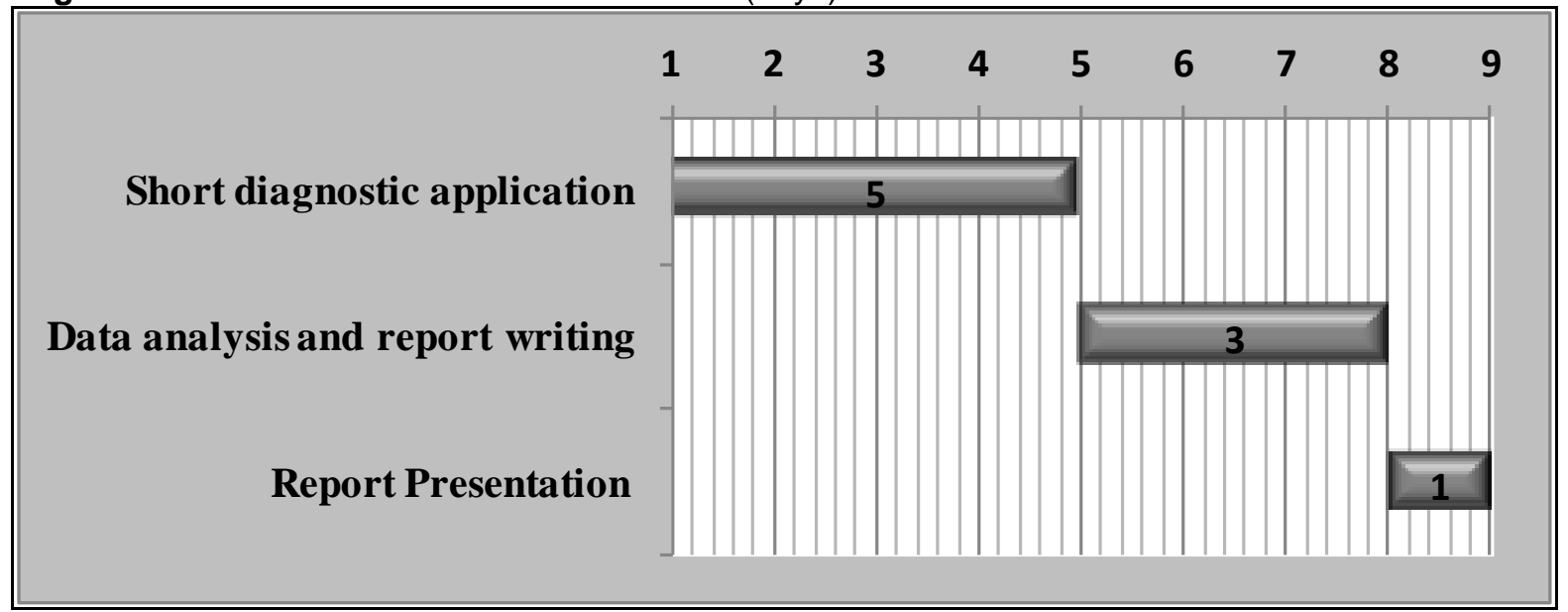

Source: Self elaboration.

\section{RESULTS}

\subsection{Demand Analysis}

This research was demanded by the need to evaluate the situation of the enterprise studied in order to evaluate the work situations through the application of Short Diagnosis helping the enterprise identify the physical aspects and other aspects related to the activities of employees and thus contribute to its evolution and future transformations of the current situation.

Initially, to avoid possible difficulties during the observations, it was necessary to negotiate the Short Diagnosis rules by explaining the objectives of the diagnosis in the enterprise to the employees.

Figure 3 presents the enterprise floor plan with the location of the enterprise sectors that served as the basis for the study. 


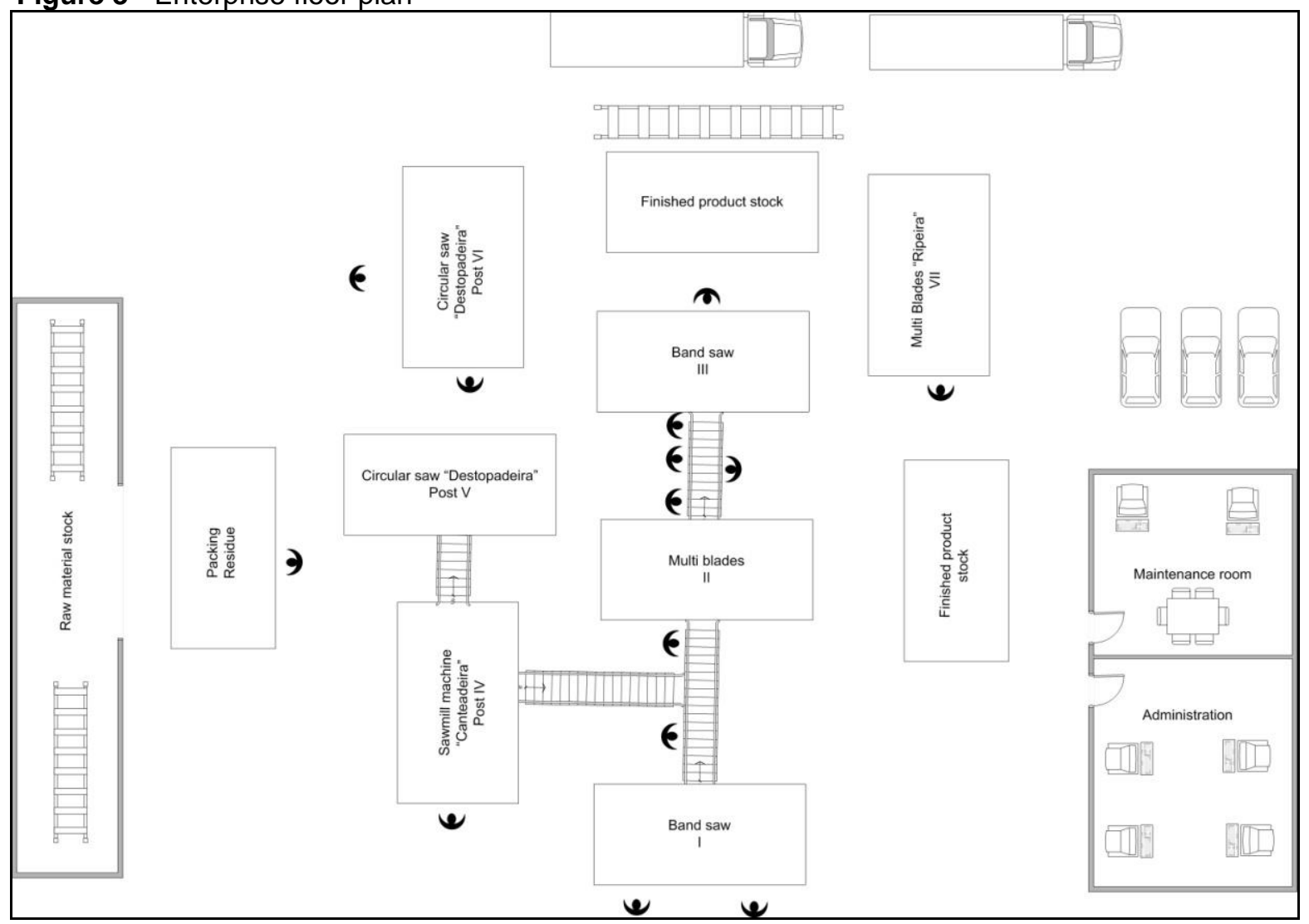

Source: Self elaboration.

\subsubsection{Enterprise operating process}

The enterprise operates in a large warehouse, where the machines are located, there is no division of sectors, the activities are distributed according to the name of the machinery, so employees consider each machine as a sector, so we will have:

- Sector 1 (seraphite): Responsible for the removal of wood pieces from the raw material (log);

- Sector 2 (multi-blades): Performs the division of the pieces in several semifinished products (square, leg-lumber, and board);

- Sector 3 (lands): Performs the cutting of the board to the required thickness;

- Sector 4 (uncoupling): Performs the cutting of products according to the size of the demand;

- Sector 5 (lane): Responsible for lath manufacturer;

- Sector 6 ("Cantiadeira"): Utilization of defective parts, for the manufacture of boards, leg shafts, and square; 
- Sector 7 (folder): Performs the cutting of the pieces used in sector 6 to the required size.

\subsubsection{Sector description and studied process}

Wood splitting is the main business process of the enterprise (Figure 4), this phase of the process starts when the raw material (log) is driven by the loader to sector 1 (seraphite). This machinery transforms the raw material into pieces of wood, and initially, the employees perform the adjustment of the log manually using the electric saw, leaving the same uniform to pass through the sawmill and after being removed the parts by the employees and placed on the running belt (manual) that are transported to sector 2 (multi-blades).

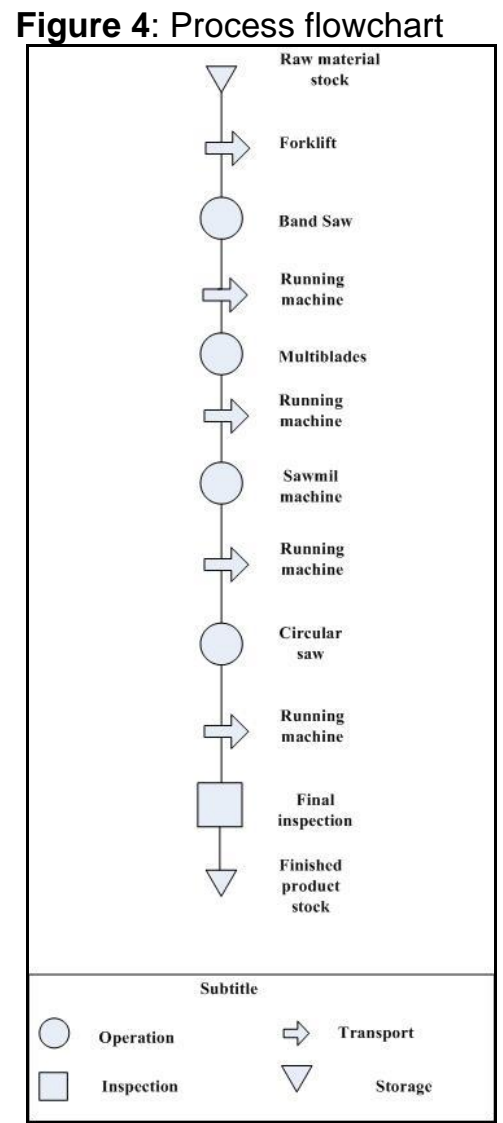

Source: Self elaboration.

Following is the flowchart of the movement in the studied sectors (Figure 4), the procedure is indicative of the movements of sector 1 (seraphite) and sector 2 (multi-blades) of the lumber manufacturing process. 


\subsubsection{Analysis of the Study population}

The composition of sector 1 (seraphite) is defined by four employees being 3 fixed and one alternative, with an average age of 30 to 35 years, while the sector 2 (multi-blades) is composed of five employees being four fixed and one alternative, with the From 27 to 45 years old, during production breaks due to maintenance, saw change, machinery breakdown, production setups, we sought to talk with the employees in order to pick up any complaints related to the improvement of the work environment. They themselves did not feel safe to comment for fear of being dismissed for complaining about their activity, and they said they are used to the work routine even if there is rotation, so they were satisfied with the duties performed.

The following figure (Figure 5) represents a mapoflowchart that corresponds to the movement of employees at the workplace performing part of the operation manually, and the movement of raw materials in the process until their dispatch. The green, yellow, red and blue colors represent steps in the manufacturing process.

The red color represents the production from the raw material to the elaboration of the final product (lumber), starting the stage with the distribution of the raw material to sector 1 (seraphite) by means of a loader, followed by the seraphite strip. and passes to sector 2 (multi-blade) where it subdivides this part, producing 3 types of semi-finished products (leg, board, and square), leg and square are taken to the final step that is in sector 6 (stripper) and the board goes through sector 3 (slits) where it will be cut according to the client's thickness, and finally taken to sector 6 (stripper) where it will cut the required size.

When sector 1 performs the part removal and it is not in good quality, this part is passed on to sector 4 ("cantiadeira") where a non-uniform part is reused and then passed to sector 5 (stripping machine) and finishing the step in the sector 6 (cutter). When sector 2 subdivides the parts, some of them do not come out of good quality, with this they are taken with the forklift to sector 7 (strips), where these products are reused for slat manufacture.

The green color of the flowchart represents the moment of loading of waste generated during production, this displacement is done manually and some of them with the forklift, this occurs several times during production, this waste disrupts pro- 
duction, because once generated they are stored right next to the machine and then taken to the packaging area where they will be packed and then shipped for sale.

The yellow color is the final stage of the sawing process (manufacturing), where the finished products are manually taken to the finished product stock where they will be inspected to check for quality, and finally exposed. Outdoor for the drying process since the enterprise has no greenhouse, it is important to note that products exposed to outdoor drying often demand their quality depending on the time that is exposed, losing 20 to $30 \%$ of the product.

The blue color is the final stage of the manufacturing process, where sawn timber that has passed the quality inspection is available for distribution which consists of loading the truck with the product for transportation to the customer. It is important to emphasize that the truck loading is performed with the same production workers, which justifies the importance of the analysis in this sector.

Figure 5: Production process mapoflowchart

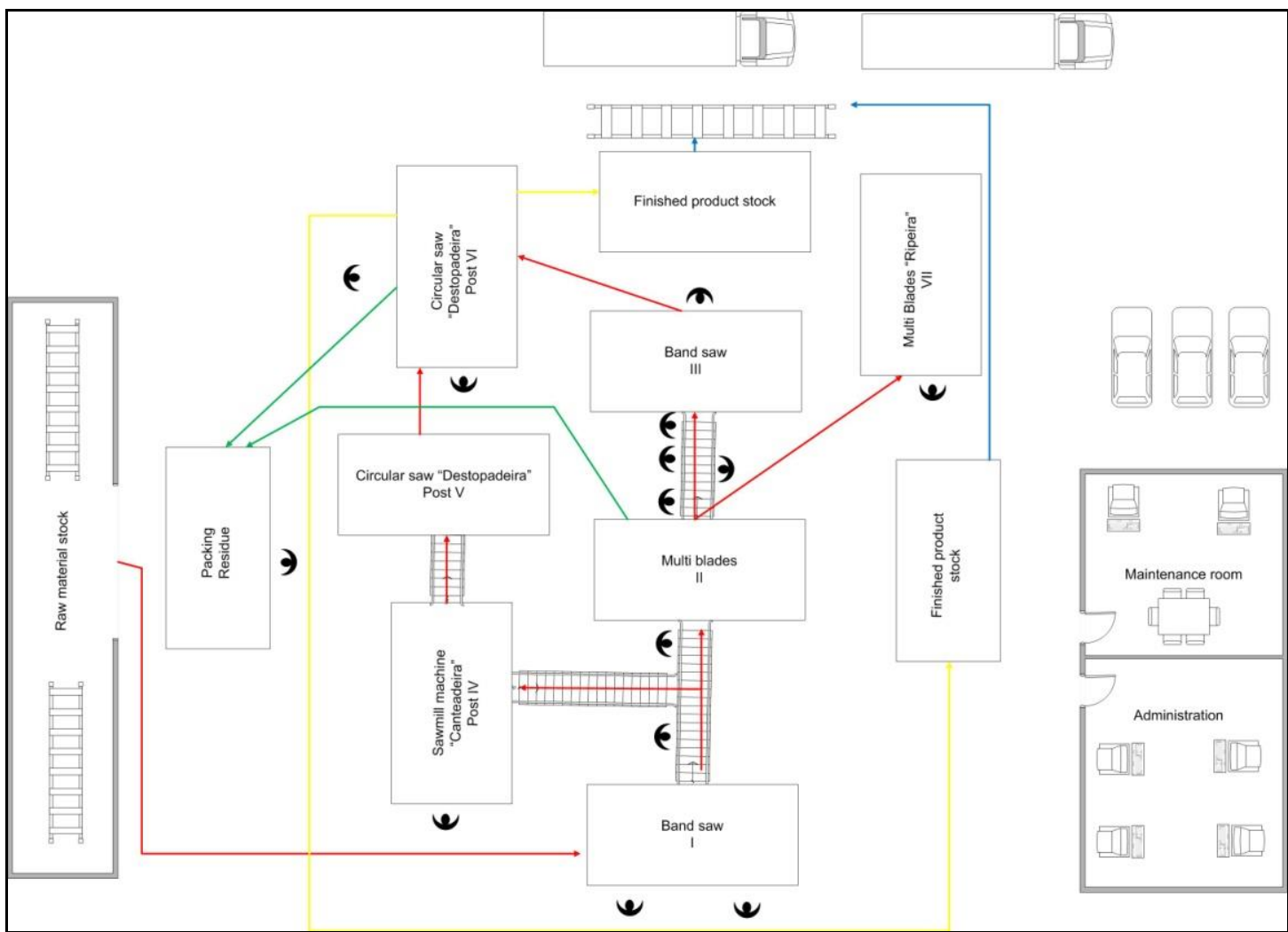

Source: Self elaboration.

4.1.4 Presupposition 
P1. The function performed in the workplace analyzed has constraints that are harmful to the health of operators.

P2. Organizational infrastructure is not suited to work activity performance.

\subsection{Diagnosis}

\subsubsection{The work of operators - sector 1 (seraphite)}

There is a small movement of operators to the sawing process because the activities are mechanized, but there is a large movement from workstation 1 (seraphite) to the maintenance room, this movement occurs due to the change of saw that happens frequently in this sector.

During the observations was measured the time and movement of employees of this sector, for each activity performed.

Some aspects were identified through observation, which will be explained in this study, regarding the biomechanical, physiological and anthropometric factors were detected, constraints such as the operators' body joints, they are not kept in neutral position when they are moving, it is necessary to know the time and stress tensions in the joints considering the requirement of the job.

There is muscle strain that leads to exhaustion after a while performing the task, the movement of forces abruptly cannot be avoided as it is a feature of the workstation as well as the inclination of the body forward and to the side which when pulling and pushing The high-speed piece of wood on the conveyor belt requires the employee to give more effort to the activity because it is not automated. They are only provided with bearings that are constantly lubricated by the employee himself to make less force in his activity.

It was also noted that the height of the conveyor belt is not ideal for the employee's height, contrary to the Regulatory Standard (NR-12), which mentions that machines and equipment must be designed, built and operated taking into account the need adapting the working conditions to the workers' psychophysiological characteristics and the nature of the work to be performed, offering conditions of comfort and safety at work, observing the provisions of NR-17. 
Regarding the movements involved in the execution of the activity, it was observed the regular manual displacement of loads and in unsuitable conditions, since as much as the activity is mechanized, the worker makes a great physical effort to move the log, requiring both forward inclination. as backward, and although the study did not apply the National Institute for Occupational Safety and Health (NIOSH) assessment method to calculate the recommended weight limit, the weight-lifting technique is questioned as they are not Accessories used to assist lifting and loading are limited by the capacity of the treadmill, which indicates that such efforts may result in the risk of low back injury or other skeletal muscle dysfunction in workers.

Regarding the temperature, it was found that the workplace has conditions of thermal discomfort, because it is an open place, has only air quality, which is dry, which results in appropriate temperature for workers, and mention that the dust (sawdust) has no open storage, so there is no way to avoid environmental dust, making the environment unhealthy which meets NRs 17 and 15.

\subsubsection{The Work of Operators - Sector 2 (Multi-Blades)}

The workers of sector 2 (multi-blades) carry out movements that have as their purpose the production of three semi-finished products, emphasizing that in this sector there are 5 (five) employees, 4 (four) fixed and an alternative, the four fixed perform activities of great physical effort. , with incorrect posture due to the anthropometric factor, the machine, and the tracks are mechanized and low for the height of the employees, considering that in this sector the employees are at risk of accident, when there is an operator error or because of the machine having problems listen to the piece of wood against the employees.

The activities of sector 2 follow the same constraints mentioned in sector 1 (seraphite) with the differential that the movements of sector 2 are performed more manually, as the machine is considered outdated requires the employee to push the piece of wood against the Machine for cutting with the highest quality, without this effort of the employee the machine is unable to cut the piece of wood.

It was also observed that both in sector 1 and sector 2 there were production stops due to machinery problems, as the enterprise does not use preventive maintenance of equipment. 


\subsection{Put in motion}

Therefore, we identified a series of key points synthesized and hierarchized in five dimensions that need to be deepened and debated between the operators and the managers of the enterprise.

1. Infrastructure of the productive area: the enterprise has an area destined to the factory yard, but it needs organization and a study that better define its physical arrangement (layout), it is indispensable to expand the physical space of the productive area for better staff allocation, increasing the production to meet the demand, considering besides the purchase of new machines to avoid the overload and stop of production and reduction of overtime, besides the illumination, visual communication, neatness and disposition of the machinery;

2. Maintenance: Concerning the maintenance of machinery, it is done correctly and this implies the efficiency, effectiveness, effectiveness, and productivity of the enterprise. sectors with machine problems and other sectors were also idle;

3. Productive Costs: In observing and talking with the production supervisor, we understand a huge amount of rework and scrap, due to non-compliant wood pieces due to production failure or even defects of nature itself, during the early stage of the process was also noted the waste of direct cost of manufacturing as electricity, rework already mentioned above and the lack of resources to reuse the waste turning into other products;

4. Ergonomics: the enterprise needs to pay attention to the use of PPE, during the visits it was noted that the employees worked without the protective equipment, emphasizing that the work environment studied has areas of noise, due to the machinery, light, taking into account It counts with the sunlight that has high temperature in the city where the enterprise is installed, sawdust in the air because of the place being opened with this being ventilated and pieces of wood speck due to the sawdust of the wood itself;

5. Loss of quality and productivity: all key aspects noted for future transformations lead to loss of product quality and productivity of the production line, which affects the economy of the enterprise. Key point diagnostics can 
drive profit and consequently allow the organization to evolve making it more competitive in the market.

\section{DISCUSSION}

Transformation proposals for future ergonomic and/or organizational projects resulting from the three basic stages of Short Diagnosis include:

Total Productive Maintenance (TPM): Tool that seeks to improve the production system, eliminating losses, ensuring quality, reducing downtime, reducing ongoing process costs. In addition, it develops knowledge capable of re-educating people for prevention and continuous improvement actions, ensuring increased availability of machinery, generating higher productivity, better performance and personal motivation by employees without much additional investment (PETRÔNIO, 2005; AHUJA; KHAMBA, 2008; SLACK, CHAMBERS; JOHNSTON, 2010; AGUSTIADY; CUDNEY, 2015).

Total productive maintenance is based on three fundamental principles: improvement of people, equipment and total quality (PETRÔNIO, 2005; AHUJA; KHAMBA, 2008; SLACK, CHAMBERS; JOHNSTON, 2010; AGUSTIADY; CUDNEY, 2015).

It must be implemented in the right way and to the required needs, as a poorly executed program returns to the detriment and discredit of the employees. To avoid this, an analysis should be made and the TPM philosophy adjusted to the characteristics of each enterprise as the physical arrangement of the industrial facilities; productive capacity; the variety of products; business scale; among others. To develop TPM with the organization there are steps to be taken and the details are specific to each enterprise, as the objectives and goals are also unique in each case. But there are foundations common to all, which are called basic pillars of TPM support (NAKAJIMA, 1989; TAKASHI; OSADA, 1993).

Implementation of Total Quality Management: There are two basic objectives that Quality Management seeks to achieve: (1) the development of mechanisms that guarantee the survival of the organization and (2) mechanisms that enable its permanent and continuous evolution (AHIRE et al., 1996; AHIRE; RAVICHANDRAN, 2001; PRAJOGO; BROWN, 2006; PALADINI, 2004; OLIVEIRA et al., 2017). Adopt 
the PDCA and 5S Program (HIRANO, 1995; KUMAR; KUMAR, 2012; SINGH, RASTOGI; SHARMA, 2014) as a methodology for problem-solving, controls and continuous improvement.

Adoption of lean manufacturing tools: this supports standardized work, process adherence and enables improvements. It would also be appropriate to apply Poka-Yoke, which has as its basic functions the shutdown of a production system (machine, line, equipment, etc.), the control of the pre-established product and/or process characteristics and signaling when detecting abnormalities (SPEARMAN; ZAZANIS, 1992; KUMAR; THOMAS, 2002; WOMACK et al., 2004; HOPP; SPEARMAN, 2013).

Implementation of Regulatory Standards (NRs) in the productive environment: NRs are fundamental for occupational safety and health, in the case of the enterprise studied, intensify the adoption of NR-6 (related to the use of personal protective equipment - PPE), implementation of NR-12 (occupational safety of machinery and equipment), NR-9 (Environmental Risk Prevention Program - PPRA), NR-7 (Occupational Health and Medical Control Program - PCMSO), and NR-17 related to ergonomics (BRASIL, 1978a; 1978b; 1978c; 1978d; 1978e).

Modification of the productive layout: in order to improve the organization of the enterprise, it was observed that the distribution of the machines does not occur efficiently. The layout is critical to industrial health because if machinery and processes are not in harmony, production will be more vulnerable to control errors, inaccuracy of time, problems with internal delivery logistics, risk of missing or damaged parts. and products and bottleneck generation, as well as providing employee safety risks (PETRÔNIO, 2005; SLACK, CHAMBERS; JOHNSTON, 2010; TURATI; MORONI FILHO, 2016; GURGEL et al., 2017).

Production Planning, Scheduling, and Control (PPCP): Given that the enterprise does not produce all year round due to lack of raw material, it is also unaware of the quantity that must be produced daily (the enterprise does not meet $50 \%$ of the demand), the adoption of the PPCP is necessary. Production planning, scheduling, and control is a system that receives information on inventories, expected sales, product line, production mode, production capacity and transforms the information into manufacturing orders, so the adoption of the PPCP system corresponds to plan and manage (PETRÔNIO, 2005; SLACK, CHAMBERS; JOHNSTON, 2010). 
Reuse of wood waste: The reuse of waste resulting from production has both economic and environmental importance because it generates economic return throughout the production process with less environmental impact. In the research, it was observed the great production of waste and its inadequate storage. According to Franceschin (2004), the waste generated by the logging enterprise is a material that poses a threat to the environment when disposed of improperly. This material, however, can be used alternatively to increase the revenues of some logging establishments. Cassilha et al. (2004), state that wood residues can be used in the lining of farms, corrals, and bays, as well as in agriculture, to increase soil moisture retention, since most of these residues have no toxic substances to the environment. In contrast, Gomes \& Sampaio (2004) state that the process of composting, power generation and manufacturing of small wood artifacts represents the main alternatives for waste wood management.

Ergonomics: The enterprise must pay attention to this area by conducting studies at all its employees' jobs, which is important for the health of the enterprise's employees and is part of the development and organizational maturity concern with the working conditions of the operators. Observing these key factors can lead to improvements in the quality of processes and products, as well as the quality of life of employees and the sawmill's organizational environment. Suggested ergonomic solutions include:

- Ergonomic Solution 1: Application of pre-structured ergonomic intervention models to identified critical activities, especially Ergonomic Checkpoints PVE, Ovako Working Posture Analysis System - OWAS, Rapid Entire Body Assessment - REBA, Rapid Upper Limb Assessment - RULAA, and National Institute for Occupational Safety and Health - NIOSH (IIDA, 2005; TEIXEIRA, OKIJIMOTO; GONTIJO, 2011; CARDOSO JÚNIOR, 2006; PAVANI, 2007; HIGNETT; MCATAMNEY, 2000; KARWOWSKI; MARRAS, 2019);

- Ergonomic Solution 2: Application of Ergonomic Work Analysis (AET) based on French-language ergonomics (GUÉRIN et al., 2001);

- Ergonomic solution 3: use of machines, equipment to facilitate the worker's life, such as (1) electric hoists, suction cups and other means of han- 
dling loads between two stations; (2) miscellaneous cargo handling equipment in warehouse and warehouse environments;

- Ergonomic solution 4: adoption of workplace ergonomics awareness through (1) internal communication actions; (2) promotion of training for the correct use of machinery; (3) occupational gymnastics establishment; and (4) use of ergonomic equipment (wrist rests, adapted footrests, benches, and chairs);

- Ergonomic solution 5: use of job enrichment and job rotation (SAINTVICENT et al., 2003; OUELLET et al, 2003; VEZINA, 2003).

The Short Diagnosis is an activity conducted by actors who have diversified competences, for the best performance in the research it was necessary to fit the enterprise's daily life, respect its limitations and difficulties encountered daily, know how to listen and clarify why of the comments (SILVA, 2007).

Short Diagnosis positively interferes with man's relationships with work through the various aspects that this methodology adopts. The results of applying this approach resemble the benefits pointed out in Deltor \& Guérin (1994), Silva (2007), Costa et al. (2015) and Coelho, Albuquerque \& Vaz (2015) confirming the usefulness of Short Diagnosis as an effective methodology for future ergonomic intervention projects based on a faster social return.

\section{CONCLUSION}

In this study, we chose the application of Short Diagnosis in a sawmill in the state of Amazonas/Brazil which provided an assessment in a short period of time, which allowed us to know the enterprise, identifying some ergonomic aspects with a view to improving the work situation in the enterprise. Noting that the Short Diagnosis proved to be effective, as it made it possible to know the enterprise and its demands. Thus, the objective of the work was achieved.

The main results are: (1) ease of application of the approach (Short Diagnosis) that allowed the enterprise to know about it in a short period of time (nine days), (2) provided owners insights for future projects due to the identification of the improvement points related to productive and management factors; (3) recognition of ergo- 
nomic aspects in the observed activities (seraphite and multi-blades) during the application of the diagnosis; (4) also improved the enterprise's internal communication, as well as promoting improvement proposals and (5) recommendations for organizational and ergonomic projects.

Regarding the limitations of the study, it is necessary to apply this methodology to a larger sample to observe its positive and negative aspects, because the application of Short Diagnosis was only in a medium-sized enterprise. Also as a limitation was the employees' fear of issuing more detailed information about all the constraints that their activities cause for fear of being dismissed. It is suggested as a proposal for future research the application of this methodology in other micro and small companies as a way to collaborate for the organizational development.

Therefore, the Short Diagnosis was useful because it provided a quick analysis of the studied enterprise, identifying and analyzing the problems both in the organizational and ergonomic aspects, aiming at the improvement of the work situations in the MSEs, through a communication between the employees and employers to make changes in the enterprise's work process. The relevance of the study lies in the application of an ergonomic intervention method that makes it possible to identify initial ergonomic demands, as well as aspects related to the improvement of the production process, the work systems and the organization as a whole.

\section{REFERENCES}

ABRAF -Associação Brasileira dos Produtores de Florestas Plantadas. Relatório estatístico da ABRAF 2012. Brasília: ABRAF, 2012.

ABRAHÃO, J. et al. Introdução à ergonomia: da prática à teoria. São Paulo: Edgard Blucher, 2009.

AGUSTIADY, T.K.; CUDNEY, E.A. Total productive maintenance: strategies and implementation guide. 1. ed. Flórida: CRC Press, 2015. https://doi.org/10.1201/b18641

AHIRE, S. L., GOLHAR, D. Y. ; WALLER, M. A. Development and validation of TQM implementation constructs. Decision Sciences, v. 27, n. 1, p. 23-56, 1996.

https://doi.org/10.1111/j.1540-5915.1996.tb00842.x

AHIRE, S. L., ; RAVICHANDRAN, T. An innovation diffusion model of TQM implementation. J. IEEE Transactions on Engineering Management, v. 48, n. 4, p. 445-464, 2001. https://doi.org/10.1109/17.969423 
AHUJA, I.P.S., KHAMBA, J.S. Total productive maintenance: literature review and directions. International Journal of Quality \& Reliability Management, v. 25, n. 7, p. 709-756, 2008. https://doi.org/10.1108/02656710810890890

ARACT - Association Régionale pour L'Amélioration des Conditions de Travail. Elvie, une méthode de diagnostic et prévention des risques psychosociaux au travail. France: Aract, 2009.

ASSUNÇÃO, A. A.; SAMPAIO, R. F.; NASCIMENTO, L. M. B. Agir em empresa de pequena e média dimensão para promover a saúde dos trabalhadores: o caso do setor de alimentos e bebidas. Revista Brasileira de Fisioterapia, v. 14, n. 1, p. 52-9, 2010. ttps://doi.org/10.1590/S1413-35552010000100009

BRASIL. Ministério do Trabalho e Emprego. Portaria MTb $\mathbf{n}^{\circ} \mathbf{3 . 2 1 4}$, de 08 de junho de 1978. NR-6 - Equipamento de Proteção Individual - EPI, Brasília, DF, 08 jun. 1978a.

BRASIL. Ministério do Trabalho e Emprego. Portaria MTb $\mathbf{n}^{\circ} \mathbf{3 . 2 1 4}$, de 08 de junho de 1978. NR-7 - Programa de Controle Médico de Saúde Ocupacional - PCMSO, Brasília, DF, 08 jun. $1978 b$.

BRASIL. Ministério do Trabalho e Emprego. Portaria MTb $\mathbf{n}^{\circ} \mathbf{3 . 2 1 4}$, de 08 de junho de 1978. NR-9 - Programa de Prevenção de Riscos Ambientais - PPRA, Brasília, DF, 08 jun. $1978 \mathrm{c}$.

BRASIL. Ministério do Trabalho e Emprego. Portaria MTb $\mathbf{n}^{\circ} \mathbf{3 . 2 1 4}$, de 08 de junho de 1978. NR12 - Segurança no trabalho em máquinas e equipamentos, Brasília, DF, 08 jun. 1978d.

BRASIL. Ministério do Trabalho e Emprego. Portaria MTb n 3.214, de 08 de junho de 1978. NR-17 - Ergonomia, Brasília, DF, 08 jun. 1978e.

BUREAU INTERNACIONAL DO TRABALHO. Introdução à saúde e segurança do trabaIho. Genebra: ILO, 2009.

CAMFIELD, C. R. et al.. (2006). Avaliação dos aspectos ergonômicos e das condições de trabalho em organizações madeireiras na região da Quarta Colônia. In: SIMPEP, 13., 2006. [Anais...]. Bauru, SP, 1- 9, 2006.

CARDOSO JÚNIOR, M. M. Avaliação ergonômica: revisão dos métodos para avaliação postural. Revista Produção Online, v. 6, n. 3, p. 133-154, 2006. https://doi.org/10.14488/16761901.v6i3.630

CASSILHA, A. C. et al. Indústria Moveleira e resíduos sólidos: considerações para o equilíbrio ambiental. Revista Educação e Tecnologia, São Paulo, 2004.

COELHO, M. A.; ALBUQUERQUE, E. S.; VAZ, L. G. N. Aplicação do diagnóstico curto em uma confecção da cidade de Manaus. Gestão e Saúde, v. 1, n. 1, 938-954, 2015.

COSTA, P. G. F. et al. A efetividade de metodologias de diagnóstico rápido em ergonomia em plataformas offshore: revisitando o conceito de modo degradado de funcionamento. Revista Brasileira de Saúde Ocupacional, v. 40, n. 132, p. 121-136, 2015. https://doi.org/10.1590/0303-7657000079513 
CULCHESK, A. S. et al. Análise ergonômica do trabalho em uma serraria, Fortaleza. In: ENCONTRO NACIONAL DE ENGENHARIA DE PRODUÇÃO, 35, 2015, Fortaleza, CE. [Anais...] Fortaleza, Ce: Enegep, 2015. p. 1-15, 2015.

DANIELLOU, F.; \& BÉGUIN, P. Metodologia da ação ergonômica: abordagens do trabalho real. In: FALZON, Pierre. Ergonomia. São Paulo: Blucher, 2007.

DELTOR, S.; \& GUÉRIN, F. Intentions, modalities et demarche d'évaluation des diagnostics. Le Cahiers de L'Anact: évaluation du diagnostic court, n. 1, 3-6, 1994.

DUL, J.; \& WEERDMEESTER, B. Ergonomia na prática. 2. ed.rev. e ampl. São Paulo: Edgard Blucher, 2004.

ELEOTÉRIO, J. R.; STORCK, L.; LOPES, J. S. Caracterização de peças de madeira produzidas em Serraria visando o controle de qualidade. Revista Ciência Florestal, Santa Maria. v. 6 , n. 1, p. 89-99, 2012. https://doi.org/10.5902/19805098328

FRANCESCHIN, G. L. Biomassa de madeira pode gerar 28 MW de energia. FSP Saneamento e Meio Ambiente, 2004.

FUNDACENTRO. Pontos de verificação ergonômica: soluções práticas e de fácil aplicação para melhorar a segurança, a saúde e as condições de trabalho. Rio de Janeiro: Fundacentro, 2001.

GOMES, J. I.; SAMPAIO, S.S. Aproveitamento de resíduos de madeira em três empresas madeireiras do estado do Pará. Belém: Embrapa, 2004.

GUÉRIN, F. et al. Compreender o trabalho para transformá-lo: a prática da ergonomia. São Paulo: Edgar Blucher, 2002.

GUERRA, E. L. A. Manual de pesquisa qualitativa. Belo Horizonte: Grupo Ănima Educação, 2014.

GURGEL, R. F.; HÉKIS, H.R.; SOUZA, R.P.; MOURA, L.C.M.; SIDRIM, M.L.; SILVA, L.C.F. Implementação de um novo layout visando à competitividade global no setor de customização da maior indústria de confecção de vestuário da América Latina. Future Studies Research Journal, v. 9, n. 3, p. 69-91, 2017. https://doi.org/10.24023/FutureJournal/2175$\underline{5825 / 2017 . v 9 i 3.319}$

HIGNETT, S.; MCATAMNEY, L. Rapid Entire Body Assessment (REBA). Applied Ergonomics, v. 31, n. 2, p. 201-205, 2000. https://doi.org/10.1016/S0003-6870(99)00039-3

HIRANO, H. 5 Pillars of the visual workplace: the source book for 5 S implementation. NewYork: Productivity Press, 1995. https://doi.org/10.4324/9781482278057

HOOP, W.J., SPEARMAN, M.L. A ciência da fábrica. 3. ed. Porto Alegre: Bookman, 2013.

HUGHES, R. E.; NELSON, N. A. Estimating investment worthiness of an ergonomic intervention for preventing low back pain from a firm's perspective. Applied Ergonomics, v. 40, n. 3, p. 457-463, 2009. https://doi.org/10.1016/j.apergo.2008.10.004

IIDA, I. Ergonomia: projeto e produção. 2. ed. rev. e ampl. São Paulo: Edgard Blucher, 2005. 
ILO - International Labour Office; \& IEA - International Ergonomics Association. Ergonomic checkpoints in agriculture: practical and easy-to-implement solutions for improving safety, health and working conditions in agriculture. 2. ed. Geneva: ILO/IEA, 2014.

KARWOWSKI, W.; MARRAS, W. Occupational ergonomics: principles of work design. Flórida: CRC Press, 2019.

KUMAR, A., THOMAS, S. A. Software tool for screening analysis of lean practices. Environmental Progress, v. 21, n. 3, p. 12-16, 2002. https://doi.org/10.1002/ep.670210308

KUMAR, K.; KUMAR, S. Steps for implementation of 5s. International Journal of Management, IT and Engineering, v. 2, n. 6, p. 402-416, 2012.

LAVILLE, A. Referências para uma história da ergonomia francófona. In: FALZON, Pierre (ed). Ergonomia. São Paulo: Blucher, p. 21-32, 2007.

MARCONI, M. A.; LAKATOS, E. M. Metodologia científica. 5. ed. São Paulo: Atlas, 2008.

MELLO, C. H. P. et al. Pesquisa ação na engenharia de produção: proposta de estruturação para sua condução. Produção, v. 22, n. 1, 1-13, 2012. https://doi.org/10.1590/S0103$\underline{65132011005000056}$

MILES, A. K.; PERREWE, P. L. The relationship between person-environment fit, control, and strain: the role of ergonomic work design and training. Journal of Applied Social

Psychology, v. 41, n. 4, p. 729-772, 2011. https://doi.org/10.1111/j.1559-1816.2011.00734.x

MORAES, A. M; MONT'ALVÃO, C. R. Ergonomia, conceitos e aplicações. 2. Ed. Rio de Janeiro: $2 A B, 2000$. Serie Oficina.

NAKAJIMA, S. Introdução ao TPM - Total Productive Maintenance. São Paulo: IMC Internacional Sistemas Educativos, 1989.

NUNES, P. A.; MELO, C. O.; TEIXEIRA, D. A participação do setor madeireiro na economia das microrregiões geográficas do Paraná - 2009. Revista Brasileira de Agropecuária Sustentável, v. 2, n. 1, p. 8-20, 2012.

OLIVEIRA, G.S.; CORRÊA, J.E.; BALESTRASSI, P.P.; MARTINS, R.A.; TURRIONI, J.B. Investigation of TQM implementation: empiracal study in brazilian ISO 9001 - registered SMEs. Total Quality Management \& Business Excellence, v. 30, n. 5-6, p. 641-659, 2017. https://doi.org/10.1080/14783363.2017.1328273

OUELLET, S.; VEZINA, N.; CHARTRAND, J.; PERRIER, P.P.; MALO, J.L. L'implantation de la rotation de postes: un exemple de démarche préalable. Pistes, v. 5, n. 2, p. 1-24, 2003. https://doi.org/10.4000/pistes.3322

PALADINI, E. P. Gestão de qualidade: teoria e prática. 2. ed. São Paulo: Atlas, 2004.

PAVANI, R. A. Estudo ergonômico aplicando o método Occupational Repetitive Actions (OCRA): uma contribuição para a gestão da saúde no trabalho. 2007. 134 f. Dissertação (Mestrado) - Curso de Gestão Integrada em Saúde do Trabalho e Meio Ambiente., Senac, São Paulo, 2007.

PETRÔNIO, G. M. Administração da produção. 2.ed. rev..aum e atual. São Paulo: Saraiva, 2005. 
PRAJOGO, D. I., \& BROWN, A. Approaches to adopting quality in SMEs and the impact on quality management practices and performance. Total Quality Management \& Business Excellence, v. 17, n. 5, p. 555-566, 2006. https://doi.org/10.1080/14783360600588042

SAINT-VICENT, M.; VEZINA, N.; DUFOUR, B.; SAINT-JACQUES, Y.; CLOUTIER, E. La rotation des postes: ce qu'en present des travailleurs d'une usine d'assemblage automobile. Pistes, v. 5, n. 2, p. 1-21, 2003. https://doi.org/10.4000/pistes.3320

SILVA, E. L.; MENEZES, E. M. Metodologia da pesquisa e elaboração de dissertação. Florianópolis: UFSC, 2005.

SINGH, J., RASTOGI, V.; SHARMA, R. Implementation of 5S practices: a review. Uncertain Supply Chain Management, 2, 155-162, 2014. https://doi.org/10.5267/j.uscm.2014.5.002

SILVA, G. C. C. Abordagem ergonômica em PMEs: um estudo de caso numa indústria de pneus remoldados. Dissertação de mestrado (Engenharia de produção) - UFRJ. Rio de Janeiro, 2007.

SLACK, N.; CHAMBERS, S.; JOHNSTON, R. Operations management. 6. ed. England: Pearson Education, 2010.

SPEARMAN, M. L., ZAZANIS, M. A. Push and pull production systems: issues and comparisons. Operations Research, v. 40, n. 3, p. 521-532, 1992.

https://doi.org/10.1287/opre.40.3.521

TAKASHI, Y.; OSADA, T. TPM/MTP: manutenção produtiva total. São Paulo: IMAM, 1993.

TEIXEIRA, E. R., OKIJOMOTO, M. L. R., GONTIJO, L. A. Índice de levantamento da equação do niosh e lombalgia. Revista Produção Online, v. 11, n. 3, p. 735-756, 2011.

https://doi.org/10.14488/1676-1901.v11i3.710

TURATI, S.A., MORONI FILHO, E. Reorganização do arranjo físico da caldeiraria de uma empresa do setor metalomecânico por meio do método de Planejamento Sistemático de Layout - SLP. Gepros, v. 11, n. 2, p. 39-51, 2016. https://doi.org/10.15675/gepros.v11i2.1391

VÉZINA, N. Implantation de la rotation: quells sont les enjeux? Quelles sont les balises? Pistes, v. 5, n. 2, p. 1-20, 2003. https://doi.org/10.4000/pistes.3318

VIDOR, F. L. R.; PIRES, M. J. R.; DEDAVID, B. A.; MONTANI, P. D. B.; \& GABIATTI, A. Inspection of Wooden Poles in Electrical Power Distribution Networks in Southern Brazil. IEEEInstitute of Electrical and Electronics Engineers, v. 25, p. 479-484. 2010. Disponível em: http://ieeexplore.ieee.org/stamp/stamp.jsp?arnumber=5345689. Acesso em: 15 julho. 2018.

WOMACK, J. P., JONES, D. T., \& ROOS, D. A máquina que mudou o mundo. 10. ed. Rio de Janeiro: Elsevier, 2004. https://doi.org/10.1109/TPWRD.2009.2034913

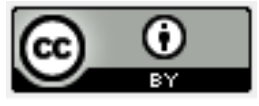

Artigo recebido em: 03/05/2020 e aceito para publicação em: 06/09/2020

DOI: $\underline{10.14488 / 1676-1901 . v 20 i 3.4046}$ 